\title{
Supplementation of Black Soldier Fly (Hermetia illucens) on Activity and Capacity Phagocytic Macrophage of Laying Hens
}

\author{
Irawan $\mathrm{AC}^{1}$, Rahmawati $\mathrm{N}^{2}$, Astuti $\mathrm{DA}^{3 *}$, Wibawan $\mathrm{IWT}^{4}$ \\ ${ }^{1}$ Study Program of Nutrition and Feed Technology, Faculty of Animal Science, IPB University, \\ Jl. Agatis Kampus IPB Kec. Dramaga, Bogor, West Java 16680, Indonesia \\ ${ }^{2}$ Animal Science Study Program, Faculty of Agriculture, Kadiri Islamic University, \\ Jl. Sersan Suharmaji No.38, Manisrenggo, Kediri, East Java 64128, Indonesia \\ ${ }^{3}$ Department of Nutrition and Feed Technology, Faculty of Animal Science, IPB University, \\ Jl. Agatis Kampus IPB Kec. Dramaga, Bogor, West Java 16680, Indonesia \\ ${ }^{4}$ Department of Parasitology and Pathology, Faculty of Veterinary Medicine, IPB University, \\ Jl. Agatis Kampus IPB Kec. Dramaga, Bogor, West Java16680, Indonesia \\ E-mail: dewiapriastuti86@gmail.com
}

(received 18-08-2019; revised 16-12-2019; accepted 16-12-2019)

\begin{abstract}
ABSTRAK
Irawan AC, Rahmawati N, Astuti DA, Wibawan IWT. 2019. Suplementasi black soldier fly (Hermetia illucens) untuk aktivitas dan kapasitas makrofag fagositosis pada ayam petelur. JITV 24(4): 182-187. DOI: http://dx.doi.org/10.14334/jitv.v24i4.2025

Larva Black Soldier Fly bersifat sebagai antibiotik alami. Pemanfaatan larva BSF dalam ransum unggas sebagai alernatif sumber protein konvensional, diharapkan dapat meningkatkan status kekebalan dan menjaga kesehatan ternak sehingga mengurangi penggunaan antibiotic growth promoters (AGP). Penelitian ini bertujuan mengevaluasi pengaruh jenis pemberian protein BSF terbaik untuk mengetahui status kesehatan ayam petelur berdasarkan aktivitas dan kapasitas fagositosis makrofag terhadap Staphyllococcus aureus non protein A. Hasil penelitian ini menunjukkan bahwa perlakuan BSF ekstrak (P3) memiliki nilai kapasitas fagositosis tertinggi, hal ini membuktikan BSF ekstrak dapat memicu sel makrofag bekerja maksimal memfagosit sel bakteri atau partikel asing. Rataan nilai aktivitas dan kapasitas fagositosis makrofag peritoneum menunjukkan perlakuan BSF ekstrak (P3) tertinggi, masing - masing sebesar $91.34 \pm 0.38 \%$ dan 22.84 bakteri makrofag $^{-1}$.
\end{abstract}

Kata Kunci: Aktivitas dan Kapasitas Fagositosis Makrofag Peritoneum, Antibiotic Growth Promoters (AGP), Black Soldier Fly (BSF)

\section{ABSTRACT}

Irawan AC, Rahmawati N, Astuti DA, Wibawan IWT. 2019. Supplementation of black soldier fly (Hermetia illucens) on activity and capacity phagocytic macrophage of laying hens. JITV 24(4): 181-187. DOI: http://dx.doi.org/10.14334/jitv.v24i4.2025

Black Soldier Fly are natural antibiotics. It is expected that the use of BSF larvae in poultry rations as an alternative source of conventional protein will contribute to improving the immune status and maintaining animal health, thereby reducing the use of antibiotic growth promoters (AGPs). This study aimed to evaluate the effect of the best type of BSF protein for determining the health status of laying hens based on the activity and capacity of macrophage phagocytosis on the non-protein A bacterium Staphyllococcus aureus. Results of this study indicated that the BSF extract (P3) has the highest phagocytic capacity value. This result proves that the BSF extract can induce macrophage cells to optimally process bacterial cells or foreign phagocyte particles. The highest average activity value, and phagocytic capacity of peritoneal macrophages was resulted from BSF extract (P3), respectively was $91.34 \pm 0.38 \%$ and 22.84 macrophage $^{-1}$ bacteria.

Key Words: Activity and Capacity Of Phagocytic Peritoneal Macrophages, Antibiotic Growth Promoters (AGPs), Black Soldier Fly (BSF)

\section{INTRODUCTION}

The role of AGPs (antibiotic growth promoters) can increase chicken growth by $4-8 \%$ and feed conversion by $2-5 \%$ and kill pathogenic bacteria in chicken digestion track, such as, Salmonella sp., Campylobacter sp., Enterococci sp. and Escherichia coli. Negative effects of using antibiotics that are uncontrolled and inappropriate may lead to microbial resistance to antibiotics. The use of AGP increases the resistance or residues in the body, although it helps to increase chicken performance. Meeting protein needs in animal feed through the substitution of conventional food ingredients is the research focus. Fishmeal in Indonesia still depends on imports, but the price is expensive causing poultry farmers are having difficulty to maintain the business. Alternative solutions for animal protein needed at affordable prices and as a replacement for AGP, is black soldier fly (Hermetia illucens). 
Insects have advantages over casein, insects boost immunity because they contain defensins, which are components of protein that is rich in cystine ( $\mathrm{Lv}$ et al. 2016). Insects containing amino acid-derived antibacterial peptides can be used as antibacterial agents by Ravi et al. (2011), the fat content of an insectassisted insect peptide in the body will activate lysozyme enzymes so that it can increase immunity and active cell phagocytosis (Villarroel et al. 2010).

The nutrient content of BSF (Hermetia illucens) includes: energy 5,282 Kcal GE / kg, crude protein $42,1 \%$, fat $26 \%$, calcium $7,56 \%$ and phosphorus $0.9 \%$ (St-Hilaire et al. 2007: Makkar et al. 2014). It is reported that the calcium mineral contained in the BSF flour was $88 \%$ (Finke 2013). According to Rambet et al. (2016) it is possible to replace fishmeal with BSF larvae flour up to $100 \%$ for fattening diet, with the digestibility of dry matter $(57.96-60.42 \%)$, energy $(62.03-64.77 \%)$ and protein $(59-75.32 \%)$. The BSF larvae has a protein content of $40-50 \%$ and a fat content of $29-32 \%$ (Bosch et al. 2014).

Hermetia illucens also have protease, amylase and lipase enzymes. Proteases convert proteins into amino acids, amylases convert starch into maltose and lipases convert fats into fatty acids and glycerol (Kim et al. 2011). BSF larvae are natural antibiotics. It has been reported that BSF larvae extracted with methanol solvent showed antibiotic properties in Gram-negative bacteria such as Klebsiella pneumonia, Neisseria gonorrhoeae and Shigella sonnei. Conversely, the results of the analysis also showed that larval extract was not effective for Gram-positive bacteria such as Bacillus subtilis, Streptococcus mutans and Sarcina lutea (Choi et al. 2012). According to Kim \& Rhee (2016), high-lauric BSF larvae are a type of fatty acid that acts as a natural antimicrobial agent and chitin. BSF larvae were able to reduce Salmonella enterica serovar Enteritidis populations in human feces up to 6 $\log ^{10}$ for 8 days, but were not effective for Enterococcus sp. and X174 bacteriophages (Lalander et al. 2013). These BSF larvae were able to reduce the population of Escherichia coli O157: $\mathrm{H} 7$ and Salmonella enterica serovar enteritidis in poultry feces (Erickson et al. 2004) and E. coli in dairy cows (Liu et al. 2008).

\section{MATERIALS AND METHODS}

The larvae of BSF were obtained from PT. Biocycle Indo Bogor. The larvae used were fed rations in the form of crude palm oil and harvested at the age of 15 days. After harvested, the larvae were treated in 3 forms, namely fresh BSF, dried BSF and BSF extract.

\section{Fresh/life BSF}

The method used for this treatment was self-mixing system, according to the nutrient requirements of the laying hens. The feed ingredients consisted of corn, rice bran, coconut oil, fish meal, soybean meal, $\mathrm{CaCO}_{3}$, salt, premix, methionine and lysine were evenly mixed in the base ration for the control treatment, while for the fishmeal was reduced into $5 \%$, and fresh BSF was given upto $8 \%$. Fresh BSF was administered at top of basal diet (topping) in the tray.

\section{Dried BSF}

The first stage of dried BSF production was to separate pupa from the cocoon layer by washing and steaming at $90^{\circ} \mathrm{C}$ for 10 minutes. The larvae were then heated to $55^{\circ} \mathrm{C}$ for 24 hours to remove the water. Then the larva was ground to flour with a blender and put in airtight plastic. The percentage of fishmeal used in the basic ration was reduced to $5 \%$ and $8 \% \mathrm{BSF}$ dried. The drying process of BSF may increase the possibility of transmitting pathogenic bacteria to livestock such as Salmonella sp. (Lalander et al. 2013).

\section{Extract BSF}

The steps for producing the BSF extract were carried out according to the modified method of Choi et al. (2012). The BSF larvae were washed and steamed for 10 minutes at $90^{\circ} \mathrm{C}$, then the larvae were heated at $55^{\circ} \mathrm{C}$ for 24 hours to remove water, then the larvae were ground to flour with a blender and then with a denanol ratio of 1:10 (w/v) for 24 hours at room temperature, $2 \mathrm{x}$ filtered solution using whatman paper then use a reduced pressure rotary evaporator at $40^{\circ} \mathrm{C}$ to get BSF methanol extract.

\section{Maintenance of laying hens}

Laying hens were kept in group battery cages (4 treatments $\mathrm{x} \quad 5$ replications $\mathrm{x} \quad 10$ laying hens). Maintenance was carried out for 8 weeks, starting with the age of 18 weeks to 26 weeks. Provision of $120 \mathrm{~g} /$ head / day ration and drinking water was given in ad libitum. Provision of treatment rations was given twice a day at 08.00 am and at $03.00 \mathrm{pm}$.

\section{Activity and capacity of phagocytic peritoneal macrophages test}

This test was performed at the end of the study using 20 laying hens from 4 treatment rations, each consisting of 5 repetitions. In the first step, all hens were injected intraperitoneally with a dose of $1 \mathrm{ml}$ of Staphylococcus aureus non protein A at a dose of $1 \mathrm{ml}$ containing $10^{5} \mathrm{CFU} / \mathrm{ml}$ of bacterial particles for 4 hours. In the next phase, laying hens were slaughtered, stretched and then cuts were made on both strips. 
Table 1. The nutritional content of laying hens feed during the study

\begin{tabular}{|c|c|c|c|c|}
\hline \multirow{2}{*}{ Ingredients } & \multicolumn{4}{|c|}{ Treatment (\%) } \\
\hline & $\mathrm{P} 0$ & $\mathrm{P} 1$ & $\mathrm{P} 2$ & $\mathrm{P} 3$ \\
\hline Maize & 56.12 & 54.67 & 54.50 & 54.01 \\
\hline Bran & 7.01 & 3.49 & 5.41 & 6.23 \\
\hline Coconut oil & 1.98 & 1.95 & 1.70 & 1.96 \\
\hline Soybean meal & 22.65 & 22.45 & 20.84 & 19.86 \\
\hline Fish meal & 08.00 & 5.00 & 5.00 & 5.00 \\
\hline Fresh BSF & - & 8.00 & - & - \\
\hline Dried BSF & - & - & 8.00 & - \\
\hline Extract BSF & - & - & - & 8.00 \\
\hline $\mathrm{CaCO}_{3}$ & 3.49 & 3.66 & 3.61 & 3.70 \\
\hline Salt & 0.24 & 0.26 & 0.22 & 0.42 \\
\hline Premix & 0.20 & 0.23 & 0.36 & 0.42 \\
\hline Methionine & 0.20 & 0.12 & 0.16 & 0.21 \\
\hline Lysin & 0.10 & 0.17 & 0.20 & 0.21 \\
\hline Total & 100 & 100 & 100 & 100 \\
\hline \multicolumn{5}{|l|}{ Proximate composition ${ }^{1)}$} \\
\hline \multicolumn{5}{|l|}{ Dry Matter (\%) } \\
\hline Crude Protein (\%) & 20.16 & 20.01 & 20.00 & 20.00 \\
\hline Crude Fat $(\%)$ & 5.31 & 6.70 & 6.96 & 6.63 \\
\hline Crude Fiber (\%) & 2.78 & 2.92 & 3.20 & 3.34 \\
\hline Metabolis Energy $\left(\mathrm{kkal} \mathrm{kg}^{-1}\right)$ & 2900.55 & 2908.10 & 2901.43 & 2903.88 \\
\hline Calsium (\%) & 4.00 & 4.01 & 4.00 & 4.10 \\
\hline Phosphor (\%) & 0.36 & 0.27 & 0.27 & 0,27 \\
\hline Lysin (\%) & 0.86 & 0.87 & 0.85 & 0.88 \\
\hline Methionine (\%) & 0.44 & 0.44 & 0.49 & 0.45 \\
\hline
\end{tabular}

Calculation results based on Leeson and Summers (2005), P0: ration contains $8 \%$ fish meal; P1: ration with 5\% fish meal + 8\% fresh BSF; P2: ration with $5 \%$ fish meal $+8 \%$ dried BSF; P3: ration with $5 \%$ fish meal $+8 \%$ extract BSF.

Table 2. The average activity and capacity of phagocytosis of peritoneal macrophages against non protein A Staphylococcus aureus

\begin{tabular}{lcccc}
\hline \hline \multirow{2}{*}{ Items } & \multicolumn{4}{c}{ Treatment } \\
\cline { 2 - 4 } & $72.02 \pm 1.38^{\mathrm{d}}$ & $88.55 \pm 0.36^{\mathrm{b}}$ & $83.44 \pm 0.32^{\mathrm{c}}$ & $91.34 \pm 0.38^{\mathrm{a}}$ \\
\hline Activity (\%) & & & $\mathrm{P} 1$ & $22.84 \pm 0.55^{\mathrm{a}}$ \\
$\begin{array}{l}\text { Capacity } \\
\text { (macrophage bacteria -1) }\end{array}$ & $20.77 \pm 1.98^{\mathrm{a}}$ & $22.25 \pm 0.72^{\mathrm{a}}$ & $22.44 \pm 0.14^{\mathrm{a}}$ & 2 \\
\hline
\end{tabular}

Different superscripts on the same line show significant differences (P <0.05), P0: ration contains $8 \%$ fish meal; P1: ration with 5\% fish meal + $8 \%$ fresh BSF; P2: ration with $5 \%$ fish meal $+8 \%$ dried BSF; P3: ration with $5 \%$ fish meal $+8 \%$ extract BSF. 
Subsequently, the subcutaneous tissues of the chest and abdomen were ejected, cuts were made to the abdominal muscles along the last rib to open the abdominal cavity. Subsequently, liquid was withdrawn from the peritoneal cavity using a syringe.

Peritoneum liquid was dropped into the glass slide and smeared evenly on its surface, fixed with $100 \%$ methanol and air dried for 5 minutes. The slide was stained with $10 \%$ Giemsa solution for 25 minutes, then rinsed with distilled water and dried. The preparations were examinated under a microscope using 100 magnification. Phagocytosis activity was calculated best on percentage of macrophage cells that actively phagocyt in 50 macrophage cells. The phagocytic capacity was calculated from the total number of phagocytic bacteria divided by 50 macrophage cells. Two macrophage cells were observed, the exhibiting phagocytic activity and the lacking phagocytic activity against non-protein A Staphylococcus aureus bacteria.

\section{Statistical Analysis}

Activity and capacity of phagocytic peritoneal macrophages for laying hens were analyzed based on randomized design followed with advanced test using Duncan (Steel \& Torrie 1995). Data processing was done using computer software program of Microsoft Excel 2010 and SPSS for Windows version 21.

\section{RESULTS AND DISCUSSION}

Effect of using various BSF larvae in the diet had a significant effect $(\mathrm{P}<0.05)$ on the immunity of laying hens by examining the activity response and phagocytic capacity of peritoneal macrophages exposed to Staphyllococcus aureus non protein A.

Macrophages are cells derived from white blood cells present in tissues called monocytes (Abbas et al. 2017). Monocytes and macrophages are phagocytic cells that mainly function in the nonspecific immune system or in innate immunity. Evaluation of the activity and capacity of macrophages in this study was performed in vitro. Test results were likely to be higher than in vivo test results because the unique chemotaxis of bacteria in the body produces and accepted by macrophages, making them more active (Wibawan \& Soejoedono 2013). Mean phagocytic activity of macrophages in this study was between 72.03 and $91.35 \%$, in line with that reported by Muhsinin et al. (2016) which ranged 76.00 to $90.78 \%$ in sentin chicken genotype NRAMP-1 by Staphylococcus aureus. Average value of macrophage-phagocytic capacity of 20.77 - 22.84 macrophage-1 bacteria was higher than that reported by Poetri et al. (2008) which was 1.60 macrophage-1 bacteria in commercial single hens
(Single Comb Brown Leghorn) at 24 weeks of age and in the same range as that reported by Muhsinin et al. (2016) that was 21.76 - 22.49 macrophages-1 bacteria in Sentul genotypes NRAMP-1. The purpose of the phagocytosis-macrophage capacity test is to detect the ability of a macrophage cell to phagocytose foreign particles or bacterial cells that enter the host body. The P3 treatment has the highest value of phagocyte capacity, respectively is $91.34 \pm 0.38 \%$ and 22.84 macrophage $^{-1}$ bacteria. This shows that the BSF extract stimulates the macrophage cells to optimally engulf the bacterial cells or foreign particles of the phagocytes.

Results of this study showed that chitin content in various BSF larvae might influence the activity value and phagocytic capacity of macrophages. Comparison of three different species of BSF larvae with different chitin content suggested that: BSF live prepupa phase of $8.72 \%$ dry matter (Diener et al. 2009), BSF live pupal phase of 2.7-9.6 g / kg dry matter (Finke 2007: Kroeckel et al. 2012: Bovera et al. 2016), whereas dry BSF and BSF extract did not contain chitin, that lost during processing due to steaming. Chitin is a fibrous protein that is not water soluble but is damaged by denaturation (Klunder et al. 2012). The use of antibiotics might be reduced by the use of BSF larvae, Hong Kong caterpillars and crickets (van Hius et al. 2013).

According to Henry et al. (2015), chitin is a polysaccharide compound found in the arthropod exoskeleton that lacks the chitinase enzyme, making it indigestible to most monogastric animals, including poultry (Sánchez-Muros et al. 2014). Increased population of Lactobacillus sp. chitin content of more than $3 \%$ in the ration can reduce the population of Escherichia coli and Salmonella sp. This preserves the health of the chicken digestive tract. Populations of Lactobacillus sp. increases when the release of lysosomal enzymes such as $\beta$-glucuronidase and $\beta$ galactosidase in the digestive tract is also increased, resulting in an increase in the activity value and the phagocytic capacity of macrophages. neutrophils, eosinophils and basophils (Perdigón et al. 2001).

According to Wibawan \& Soejoedono (2013), lymphocyte cells produce antibodies in the blood serum that lead to bacterial death. Phagocytosis mediated by heterophilic cells can also lead to bacterial death. Phagocytic cells are divided into three types, namely granulocyte cells (heterophile, eosinophil, and basophil), macrophages and dendritic cells (Devereux 2002). Phagocytes are present in endogenous cells such as neutrophils and eosinophils (polymorphonuclear/PMN), monocytes and in tissues such as macrophages, Kupffer cells, histocytes, microgial cells and alveolar macrophages (Iswara 2012). Phagocytosis is the last stage in a series of processes in a nonspecific immune system in which 
immune cells (lymphoid cells) ingest foreign particles or bacterial cells that enter the body (Wibawan \& Soejoedono 2013). The formation process of macrophages is when an infection occurs, the immune system activates monocytes that pass from the blood into the tissues. The capacity of monocytes in the form of macrophages is greater than that of heterophile, ie a macrophage cell can phagocytose about 100 bacterial cells (Guyton \& Hall 2010).

\section{CONCLUSION}

Supplemention using combination of $5 \%$ fish meal $+8 \%$ extract BSF can stimulate macrophage cells to work optimally in phagocytosis to ingest foreign particles of phagocytes or gram negative bacteria in laying hens.

\section{ACKNOWLEDGEMENT}

The authors gratefully acknowledge Prof. Dewi Apri Astuti, Prof. I Wayan Teguh Wibawan and Mrs. Nurina Rahmawati for technical support, and PT. Biocycle Indo Bogor for the provision of the Hermetia illucens.

\section{REFERENCES}

Abbas AK, Lichtman AH, Pillai S. 2017. Molecular and Cellular Immunology. 9th ed. Philadelphia (US): Elsevier.

Bosch G, Zhang S, Oonincx DGAB, Hendriks WH. 2014. Protein quality of insects as potential ingredients for dog and cat foods. J Nutr Sci. 3:e29.

Bovera F, Loponte R, Marono S, Piccolo G, Parisi G, Iaconisi V, Gasco L, Nizza A. 2016. Use of Tenebrio molitor larvae meal as protein source in broiler diet: Effect on growth performance, nutrient digestibility, and carcass and meat traits. J Anim Sci. 94:639-647.

Choi W-H, Yun J-H, Chu J-P, Chu K-B. 2012. Antibacterial effect of extracts of Hermetia illucens (Diptera: stratiomyidae) larvae against Gram-negative bacteria. Entomol Res. 42:219-226.

Devereux G. 2002. The Immune System: An Overview. Calder PC, Field CJ, Gil HS, editors. Oxon (UK): CABI Pub.

Diener S, Zurbrügg C, Tockner K. 2009. Conversion of organic material by black soldier fly larvae: establishing optimal feeding rates. Waste Manag Res. 27:603-610.

Erickson MC, Islam M, Sheppard C, Liao J, Doyle MiP. 2004. Reduction of Escherichia coli O157:H7 and Salmonella enterica serovar enteritidis in chicken manure by larvae of the black soldier fly. J Food Prot. 67:685-690.
Finke MD. 2007. Estimate of chitin in raw whole insects. Zoo Biol. 26:105-115.

Finke MD. 2013. Complete Nutrient Content of Four Species of Feeder Insects. Zoo Biol. 32:27-36.

Guyton AC, Hall JE. 2010. Textbook of Medical Physiology. Missisipi (US): Elsevier Inc.

Henry M, Gasco L, Piccolo G, Fountoulaki E. 2015. Review on the use of insects in the diet of farmed fish: Past and future. Anim Feed Sci Technol. 203:1-22.

van Hius A, Van Itterbeeck J, Klunder H, Martens E, Halloran A, Giulia M, Vantomme P. 2013. Edible Insects Future Prospects for Food and Feed Security. Rome (Italy): Food and Agriculture Organization of the United Nations.

Iswara LR. 2012. Introduction to Immunology. Medan (Indones): University of Northern Sumatra.

Kim SA, Rhee MS. 2016. Highly enhanced bactericidal effects of medium chain fatty acids (caprylic, capric, and lauric acid) combined with edible plant essential oils (carvacrol, eugenol, $\beta$-resorcylic acid, trans cinnamaldehyde, thymol, and vanillin) against Escherichia coli O1. Food Control. 60:447-454.

Kim W, Bae S, Park K, Lee S, Choi Y, Han S, Koh Y. 2011. Biochemical characterization of digestive enzymes in the Black Soldier Fly, Hermetia illucens (Diptera: Stratiomyidae). J Asia Pac Entomol. 14:11-14.

Klunder HC, Wolkers-Rooijackers J, Korpela JM, Nout MJR. 2012. Microbiological aspects of processing and storage of edible insects. Food Control. 26:628-631.

Kroeckel S, Harjes A-GE, Roth I, Katz H, Wuertz S, Susenbeth A, Schulz C. 2012. When a turbot catches a fly: Evaluation of a pre-pupae meal of the Black Soldier Fly (Hermetia illucens) as fish meal substitute Growth performance and chitin degradation in juvenile turbot (Psetta maxima). Aquaculture. 364-365:345352.

Lalander C, Diener S, Magri ME, Zurbrügg C, Lindström A, Vinnerås B. 2013. Faecal sludge management with the larvae of the Black Soldier Fly (Hermetia illucens) From a hygiene aspect. Sci Total Environ. 458460:312-318

Liu Q, Tomberlin JK, Brady JA, Sanford MR, Yu Z. 2008. Black Soldier Fly (Diptera: Stratiomyidae) Larvae Reduce Escherichia coli in Dairy Manure. Environ Entomol. 37:1525-1530.

Lv M, Mohamed AA, Zhang Liwei, Zhang P, Zhang Long. 2016. A family of CS $\alpha \beta$ defensins and defensin-like peptides from the Migratory locust, Locusta migratoria, and their expression dynamics during mycosis and nosemosis. Hull JJ, editor. PLoS One. 11:e0161585.

Makkar HPS, Tran G, Heuzé V, Ankers P. 2014. State-of-theart on use of insects as animal feed. Anim Feed Sci Technol. 197:1-33.

Muhsinin M, Ulupi N, Gunawan A, Wibawan IWT, Sumantri C. 2016. Association of NRAMP1 Polymorphisms with 
Immune Traits in Indonesian Native Chickens. Int $\mathbf{J}$ Poult Sci. 15:401-406.

Perdigón G, Fuller R, Raya R. 2001. Lactic acid bacteria and their effect on the immune system. Curr Issues Intest Microbiol. 2:27-42.

Poetri ON, Soejoedono RD, Indrawati A, Wibawan IWT. 2008. Peran antibodi kuning telur (IgY) sebagai opsonion untuk pencegahan serangan mutan Streptococcus serotipe D (Streptococcus sobrinus). Berk Penelit Hayati. 13:129-134.

Rambet V, Umboh JF, Tulung YLR, Koweh YHS. 2016. Kecernaan protein dan energi ransum broiler yang menggunakan tepung maggot (Hermetia illucens) sebagai Pengganti tepung ikan. J Zootek. 36:13-22.

Ravi C, Jeyashree A, Renuka DK. 2011. Antimicrobial Peptides from Insects: an Overview. Res Biotechnol. 2:1-7.
Sánchez-Muros M-J, Barroso FG, Manzano-Agugliaro F. 2014. Insect meal as renewable source of food for animal feeding: a review. J Clean Prod. 65:16-27.

St-Hilaire S, Cranfill K, McGuire MA, Mosley EE, Tomberlin JK, Newton L, Sealey W, Sheppard C, Irving S. 2007. Fish offal recycling by the black soldier fly produces a foodstuff high in omega-3 fatty acids. J World Aquac Soc. 38:309-313.

Steel RGD, Torrie JH. 1995. Prinsip dan Prosedur Statistika. Suatu Pendekatan Biometrik. 5th ed. Jakarta (Indones): PT Gramedia Pustaka Utama.

Villarroel AYR, Fortuny RS, Belloso OM. 2010. Animal Science Reviews: Natural antimicrobials for Food Processing. Animal Science Reviews. Cambridge (USA): CABI.

Wibawan IWT, Soejoedono RD. 2013. Intisari Imunologi Medis. Bogor (Indones): Fakultas Kedokteran Hewan IPB. 